\title{
OPUS SIGNINUM - ROMAN CONCRETE WITHOUT PULVIS PUTEOLANUS : EXAMPLE OF THE SUBSTRUCTURES OF DIOCLETIAN'S PALACE
}

\author{
MARINA I. ŠIMUNIĆ BURŠIĆ \\ University of Zagreb, Faculty of Architecture \\ Kačićeva 26, HR-10000 Zagreb, Croatia \\ e-mail: marina.simunic@arhitekt.hr (*corresponding author)
}

Keywords: Roman Concrete, Opus Signinum, Vaults, Roman Imperial Palace, Emperor Diocletian, Substructures

\begin{abstract}
The palace of the Roman emperor Diocletian in Dalmatia, a Mediterranean region of Croatia, is an important Late Antique complex, whose most important buildings have been excellently preserved, including their vaults: the brick dome of the Diocletian's Mausoleum, the stone barrel vault of the so-called Jupiter's temple, and the vaults of the large substructures of the imperial apartments, constructed in Roman concrete. Because in Dalmatia there was no pozzolana (pulvis Puteolanus) - a volcanic material used for making first opus caementicium structures in the Roman world, the concrete for the vaults of the substructures of the Palace was made with crushed terracotta. This type of Roman concrete was called opus signinum. The vaults of the substructures of the imperial apartments within Diocletian's palace are important for the research of Roman concrete structures because the whole complex of vaults of various types, covering the area of approx. $150 \mathrm{~m}$ by $35 \mathrm{~m}$, has been entirely preserved. In this article, of this variety of vault types, several interesting vault solutions are analyzed.
\end{abstract}

\section{INTRODUCTION}

The most prominent example of opus signinum structure in Croatia are the vaults of the substructures of the emperor Diocletian's palace. The Palace was built at the end of the third beginning of the fourth century AD, in the vicinity of Salona, the capital of the Roman province of Dalmatia, and presumably the homeland of the Emperor. ${ }^{1}$

The Palace has been admired and researched by important European artists and scholars since the $18^{\text {th }}$ century. ${ }^{1},{ }^{2}$ Although the major part of the large complex of substructures of the Emperor's apartments was filled with trash and not accessible from the Early Middle Ages to the $20^{\text {th }}$ century, ${ }^{3}$ the interest for the Grotte, as locals called the substructures, arose already in the mid- $18^{\text {th }}$ century: Scottish architect Robert Adam attempted to do excavations, but was not allowed by the local authorities. ${ }^{1}$ Systematic excavation of the substructures began only in the mid- $20^{\text {th }}$ century. ${ }^{3}$

As the disposition of the walls of the substructures delineate and reveal the disposition of the Emperor's residential and ceremonial rooms, they have been in the focus of scientific interest; ${ }^{1,4}$ but on the other hand, the vaults of the substructures have not been given enough interest as important examples of Roman concrete structures. 


\section{ROMAN CONCRETE}

Roman concrete (opus caementicium) is one of the most important innovations in Roman ars aedificatoria. Made with volcanic material called by Romans harena fossicia ${ }^{5}$ or pulvis Puteolanus (from Puteoli - Pozzuoli), it proved to have excellent mechanical properties. This enabled major innovations in building technology and development of large-span vaults. ${ }^{6}$ There is evidence of skilful use of opus caementicium in important public buildings already in the first half of the first century BC. Substructures of the temple of Jupiter Anxur at Terracina and of the sanctuary of Fortuna Primigenia at Palestrina imply that the Roman builders by that time already had got impressive experience of building with opus caementicium. ${ }^{6,7}$

Vitruvius (first century BC) describes raw materials for making mortars and concrete, mentioning different kinds of sand. He distinguishes harena fossicia from harena fluviatica, appreciating the special characteristics of harena fossicia for making structurae caementiciae. ${ }^{5}$ Opus caementicium, first used for less important buildings, proved to be an excellent material, so that in the imperial period it was used even for the most prominent representative buildings, e.g. the Pantheon in Rome. ${ }^{6,7}$

Construction of Roman concrete structures depended on its essential component: volcanic materials found only in volcanic regions, the deposits of which are limited. Roman builders, knowing the advantages of Roman concrete, found a substitute for harena fossicia: instead of volcanic material, they used broken terracotta, i.e. tiles broken up into very small pieces, to achieve characteristics similar to those of opus caementicium made by using pozzolana. Thus,

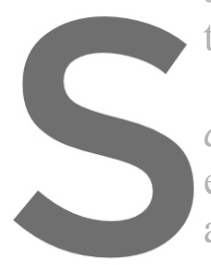
they invented opus si

\section{Opus signinum is} caementicium made w even better for this puip aqueducts, cisterns and
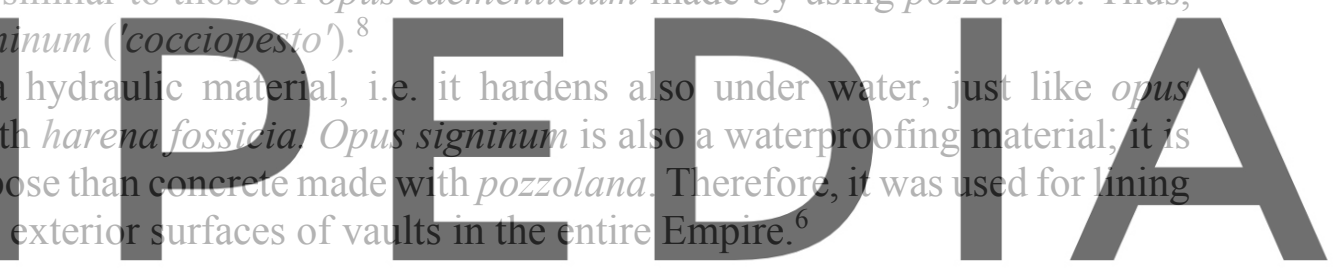

3 PALACE OF THE ROMAN EMPEROR DIOCLETIAN IN DALMATIA

Register for free at https//WwW.scipedia.com to download the version without the watermark

The palace of the Roman emperor Diocletian (284 AD - $305 \mathrm{AD}$ ) is one of the best preserved

Late Antique imperial palaces and is therefore important for the research of ancient structures and their evolution from Hellenistic period to the end of Antiquity. In the $7^{\text {th }}$ century, during Great Migrations, the fortified Palace provided shelter for the inhabitants of the nearby town of Salona and in the Middle Ages was transformed into the town of Split. ${ }^{3}$ It has been inscribed on the UNESCO World Heritage List as an outstanding example of architectural ensemble, which testifies to developments in architecture and technology. ${ }^{9}$

\subsection{Historical context}

The Palace was commissioned and built by the Roman emperor Diocletian in a relatively short period, probably from $293 \mathrm{AD}$ (when he instituted tetrarchy) to $305 \mathrm{AD}$, when he abdicated the throne by his own will.

The Palace was built on the Adriatic coast, near Salona, as Diocletian's home after his withdrawal. It was conceived as a combination of imperial villa and military camp, ${ }^{10}$ with garrison buildings in its northern part and representative buildings (religious edifices and imperial apartments) in its southern part. This concept is clearly visible in the plan of the Palace, 
conceived as castra (military camp): as a fortified complex, nearly square in plan, with cardo and decumanus and four gates at their ends; the perimetral walls of the Palace are fortified with 16 towers. ${ }^{1,4}$ The function of a lavish villa is materialized within the residential zone in the southern part of the Palace, overlooking the sea.

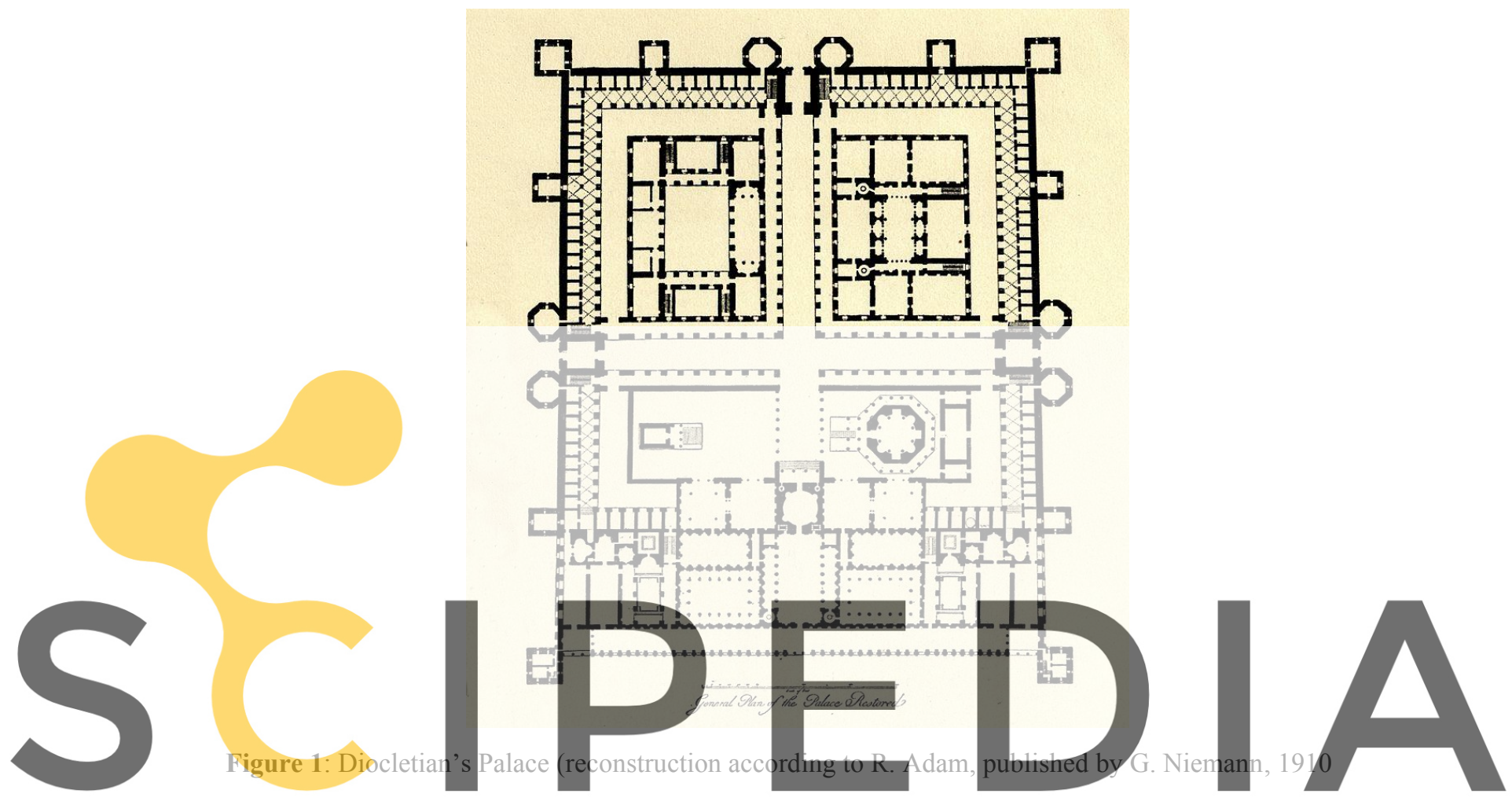

3.2. The Emperor's residential and representative buildings

Register for free at https//www.scipedia.com to download the version without the watermark According to historians' hypothesis, Diocletian decided to build his palace on the Adriatic coast in 293 AD when he reformed the administration of the huge Empire and decided to withdraw from the throne within a certain number of years. Thus, the palace near Salona was planned for the time when he would no longer be emperor. Still, the art-historians believe that the so-called residential area of the palace included also representative and ceremonial rooms - from the Prothyron, where the ex-emperor appeared before his prostrating subjects as Sol Invictus - a divine title that he retained even after his "retirement"11 - to the series of representative rooms in the western part of the apartments. The eastern part of the apartments is believed to have been a private residential area. ${ }^{3}$

Imperial apartments are situated on a higher level than other parts of the Palace: indeed, they are constructed on the platform created by a large substructure consisting of a number of thick walls and pillars carrying vaults. The imperial apartments are stretched along the south façade. The centrally positioned entrance to the palatium divides the emperor's residence into two parts.

The large central hall, preceded by the Prothyron and the Vestibule, led to the so-called Cryptoporticus, southern corridor - porch opening to a beautiful sea view through a series of large arched openings. The Cryptoporticus was the main communication corridor of Diocletian's private and ceremonial suites, running the whole length of the southern façade. 
Of the large central entrance hall only scarce traces exist. Its substructure, on the contrary, is well preserved. The same applies to most rooms of the imperial residential zone: from the Emperor's residential and ceremonial buildings, raised on the artificial platform, only the circular Vestibule and the Prothyron are preserved. ${ }^{4}$

\subsection{Substructures of the imperial apartments}

Unlike the major part of the structures of the imperial apartments, the substructures of these residential buildings have been excellently preserved. The huge complex of substructures occupies an area of approx. $150 \mathrm{~m}$ by $38 \mathrm{~m} .{ }^{12}$ It was constructed to form a raised base for the Emperor's apartments. In spite of their popular name "Diocletian's basements" or "Diocletian's cellars", they were built only to support the structures above. ${ }^{3}$ As such, they also protected the apartments from rising damp - which is important, especially considering the proximity of the sea.

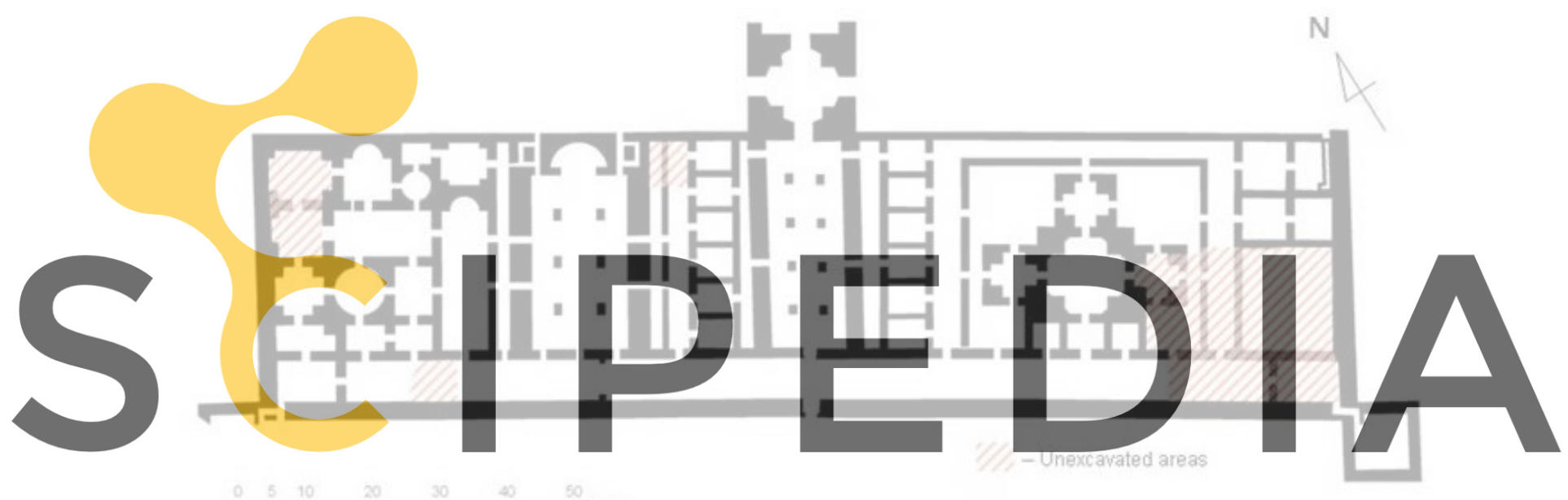

Register for free at https//www.scipedia.com to download the version without the watermark Figure 2: Substructures of the imperial apartments, plan

The substructures form a large assembly of rooms of different shapes and sizes, divided by thick bearing walls. The walls are constructed of high-quality stone masonry - opus quadratum. The massive pillars are also constructed of large stone blocks, perfectly cut and constructed with extreme precision. ${ }^{3,4}$ From historical sources it is known that the high-quality limestone for the construction of the Palace was brought primarily from the quarries on the island of Brač. ${ }^{13}$

Due to the high quality of the stone and excellent workmanship, vertical structural elements (walls and pillars) have resisted all the aggressive impacts for 17 centuries. Another reason for the excellent preservation of the substructures might be the fact that most of them were inaccessible for more than a millennium. Nevertheless, the inhabitants of Split were aware of the existence of the substructures, they even used parts of them as storage. In the $18^{\text {th }}$ century, $\mathrm{R}$. Adam describes substructures as "half sunk or vaulted story. Part of these vaults now remain entire, and at present are used by the merchants for warehouses. They lie all along that side of the Palace next to the sea... There is also another vault which runs from South to North, 
... which appears to have been a common entry to all the under-ground offices. These have been partly destroyed, and partly filled up...".

The structures of representative residential quarters were very heavy, because the imperial apartments were undoubtedly vaulted, as we can deduce from other Roman imperial palaces. Following the structural logic, the walls of the substructures were planned and built exactly on the positions of the walls of the superstructures. This has enabled the scientists to propose ideal reconstructions of the imperial quarters - from Adam and Niemann to Marasović. ${ }^{1,3,4}$

\section{VAULTS OF THE SUBSTRUCTURES OF THE IMPERIAL APARTMENTS}

The vaults of the substructures of the emperor's residential quarters display a multitude of Roman vault types: barrel vaults, cross vaults, domes, semi-domes and their variations.

The materials of the vaults have not yet been researched systematically: according to a few samplings that have been done to date, the structure of the vaults is made of a kind of opus caementicium, with caementa of tufa (very light sedimentary rock, locally called sedra), but without harena fossicia component in the mortar paste (G. Nikšić, personal communication, July 2015). Already Vitruvius knew that harena fossicia can be found only in a limited region of south-western part of Italy: “... fossicia harenaria, trans Appenninum vero, quae pars est ad Adriaticum mare, nulla inveniuntur, item Achaia, Asia, omnino trans mare, nec nominantur quidem ". ${ }^{5}$ Builders in other parts of the Roman empire had to substitute harena fossicia, the essential component of opus caementicium, with brick rubble, which also gives strength and

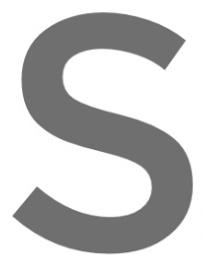
durability characteris

4.1. Cross vaults of

The large central hall Peristyle with the southe
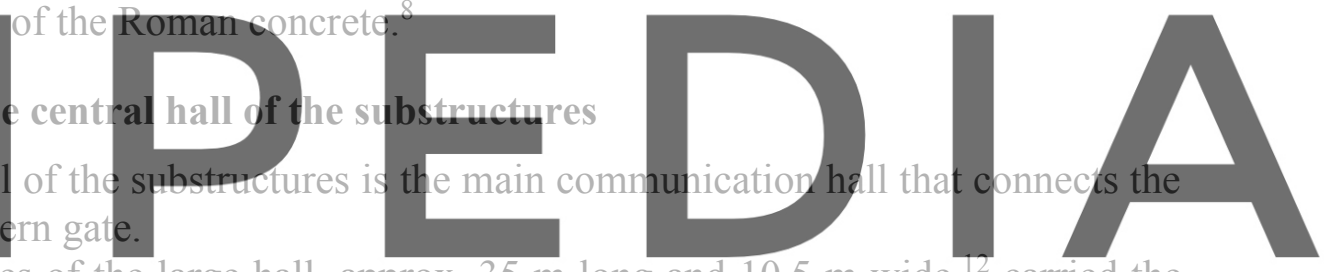

The vertical structures of the large hall, approx. $35 \mathrm{~m}$ long and $10.5 \mathrm{~m}$ wide ${ }^{12}$ carried the

Register forper cerempnial entrance hall of the imperial apartments. The representative entrance hall was presumably covered with a large-span barrel vault, as can be concluded from the very thick longitudinal walls of its substructure; hence, the large entrance hall of the imperial apartments did not have any additional supports within the large span.

Into the substructure hall of the ceremonial entrance hall, which has approximately the same dimensions as the demolished hall above it, the constructors of the Palace inserted two rows of strong pillars which divide the central substructure hall into three "aisles". In this way they reduced the spans of the vaults, and also their height. Reducing the height of the vaults was essential in order to achieve the horizontal platform for the imperial apartments.

Unfortunately, the vault of the central hall of substructures has been damaged and considered structurally unsound. The reconstruction of the Roman vault in mid-20 $0^{\text {th }}$ century was carried out with a wrong assumption that the original Roman vault was a stone masonry structure, so it was reconstructed as a modern prestressed concrete structure with intrados faced with stone (G. Nikšić, personal communication, January 2020). The fake "stone vault" can be misleading, although it can be seen that this is not a stone masonry vault, because the stone pieces are not put together as a set of voussoirs. 


\subsection{Cross vault of the largest hall in the western part of the substructures}

The original, intact (i.e. not reconstructed nor repaired) Roman concrete cross vault can be seen in the largest hall in the western part of the substructures, which is approx. $26.2 \mathrm{~m}$ long and $14.3 \mathrm{~m}$ wide. ${ }^{12}$ The room of imperial apartments above it was undoubtedly a representative (probably ceremonial) hall: a large undivided space, with a vault spanning the whole width of the room - approx. $14.3 \mathrm{~m}$.

The room below it, its substructure, is divided by two rows of strong pillars into three aisles: the central one is $5 \mathrm{~m}$ wide (clear span), and side aisles $3.10 \mathrm{~m}$. Like in the central communication hall, the pillars were probably inserted to avoid a too high rise of a vault: all the vaults of the substructures should have had the summits at approximately the same height.

In order to achieve the same height of the summits of the vaults of the central aisle and of those of side aisles, constructors had to find a solution, which is not in accordance to the orthodox rules of the ars aedificatoria. The vaults of the side aisles do not have a semi-circular cross section: they have a nearly parabolic form.
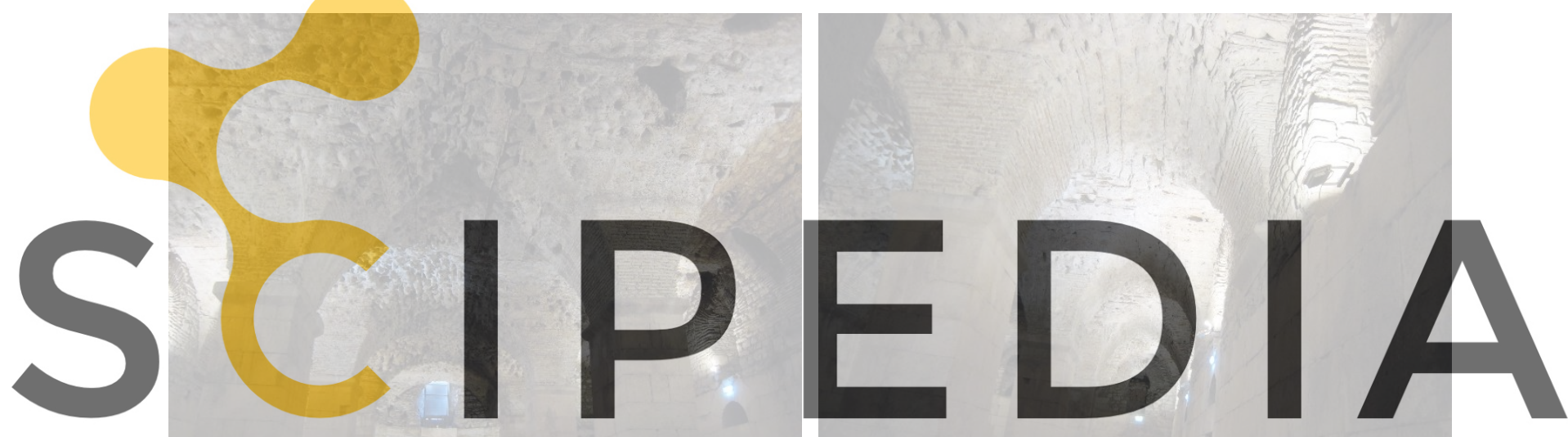

Register for free at https//www.scipedia.com to

Figure 3: The largest hall in the western part of the substructures:

cross vault in the central aisle (left) and in the side aisle (right)

(photograph by the author)

The spatial and structural concept of this hall is similar to that of the central communication hall of the substructure: it has mighty pillars $(1.75 \mathrm{~m} * 1.17 \mathrm{~m}$ in cross section) made of large stone blocks; the walls are constructed in opus quadratum to the height of approx. $4.25 \mathrm{~m}$. Above this height, the walls are constructed in opus mixtum, with layers of unhewn stone and bricks. Opus mixtum is the usual facing of Roman concrete walls: the core of the walls is made of opus signinum.

Brick was used for the springings of the cross vaults on pillars, because constructing this part of the structure required special care. ${ }^{14}$ The same applies to the vault springings on the walls. Above the springings, the vaults have opus mixtum facing, like do the upper parts of walls. Opus mixtum in this substructure hall does not have a regular, neat pattern, neither on walls nor on vaults.

In the upper parts of the vaults one can discern unhewn tufa pieces within thick mortar. Tufa pieces are not shaped and set like voussoirs of the stone vaults: indeed, they are separated by 
thick mortar. Obviously, tufa elements alone cannot create a bearing structure. They are not elements of a stone masonry, but caementa within opus signinum mortar. In this type of structure, stone pieces do not act as a masonry vault. The concrete structure, made of mortar paste with crushed tiles and tufa caementa, is the real bearing structure of the vault.

The longitudinal walls of this hall are very thick, and its orthogonal, "gable" walls are considerably thinner. The cross vaults concentrate forces in several points: the thrust of the cross vault acts on the structure in both directions (X and $\mathrm{Y}$ ). The very thick longitudinal walls indicate that the hall of the imperial apartments above this substructure hall was not divided by pillars and that it had barrel vault, with continuous thrust acting only on the longitudinal walls.

\subsection{Barrel vault of the smaller longitudinal hall}

The third-largest longitudinal rectangle hall (approx. $20.8 \mathrm{~m}$ long and $7.0 \mathrm{~m}$ wide) has a barrel Roman concrete vault. Longitudinal walls are constructed in excellent opus quadratum. The ,gable walls", i.e. the walls at the narrower sides of the hall, are constructed in opus quadratum up to the height of springings of the vault; in the upper part they are faced with opus mixtum, with unhewn stone pieces and thin horizontal layers of bricks; the core of the walls is undoubdetly of opus signinum

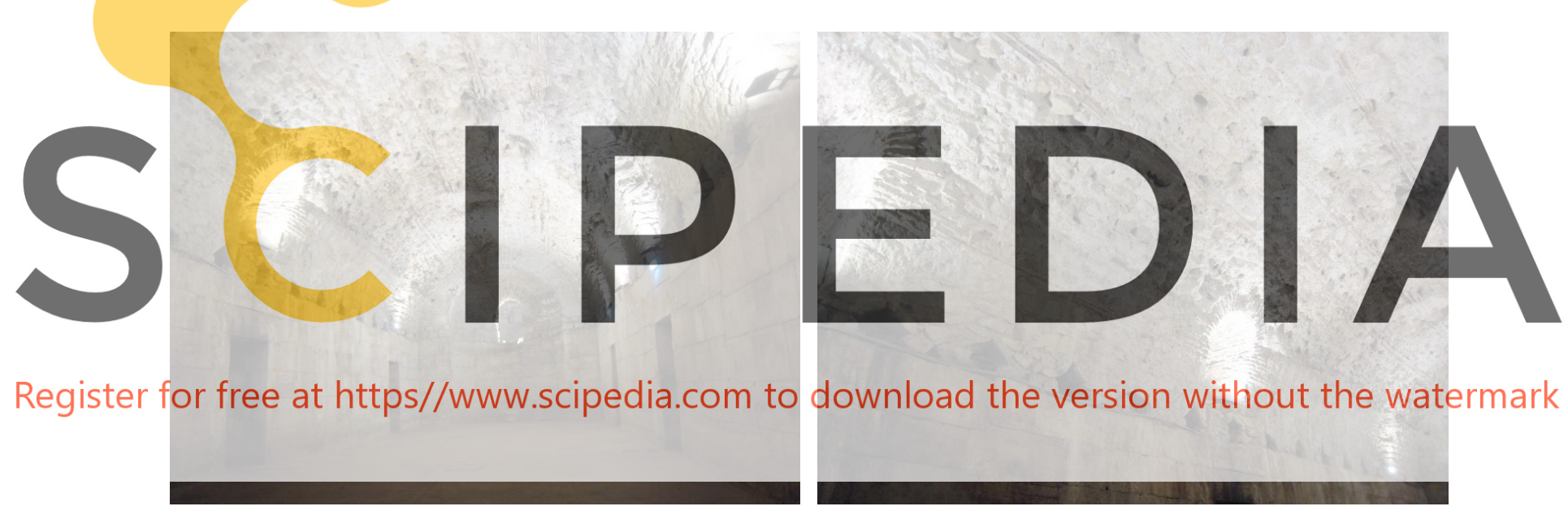

Figure 4: Barrel vault of the smaller longitudinal hall of the substructures (photograph by the author)

The barrel vault, semi-cylindrical in cross section, spanning $7.0 \mathrm{~m}$, has the intrados faced in a kind of opus mixtum, with longitudinal rows of brick and irregular pieces of tufa (sedra). The core of the barrel vault, i.e. its structural, bearing part, is obviously made of concrete.

As the substructures did not have function (except for that of bearing the imperial apartments), the intrados of vaults did not have a protecting layer of plaster. Therefore, they were exposed to adverse impacts of rising damp and saline aerosol. Materials of the vault - opus signinum and tufa - are less resistant to humidity and salinity than high-quality limestone from the island of Brač; therefore, vaults are much more damaged than pillars and walls made of limestone in opus quadratum. 


\subsection{Dome of the circular room}

The walls of the room with a circular plan (diameter $7.33 \mathrm{~m}$ ) were built in excellent opus quadratum. The lower part of the dome is faced in opus mixtum, and the upper part in thin bricks. Opus mixtum was usually a lining of a concrete core. It is reasonable to assume that the bricks of the intrados of the dome are only a lining of a much thicker dome of opus signinum. In the Palace there is a dome built exclusively of bricks: the representative Mausoleum is covered with a thin brick dome, spanning approx. $13.3 \mathrm{~m} .{ }^{15}$ This elaborate double-shell brick structure, consisting of two layers of bricks $(33 * 33 \mathrm{~cm} \text { square })^{14}$ with the inner layer constructed of fan-like relieving arches, ${ }^{16}$ which were self-supporting during the construction of its lower part, ${ }^{17,18}$ was undoubtedly constructed by specialized experts invited to the important imperial building site. ${ }^{14}$ On the other hand, in the massive substructures, built to carry the load of a superstructure, it is reasonable to suppose that the dome, like many other vaults of the substructures, was constructed of Roman concrete, and that only the intrados of the dome was lined with bricks.
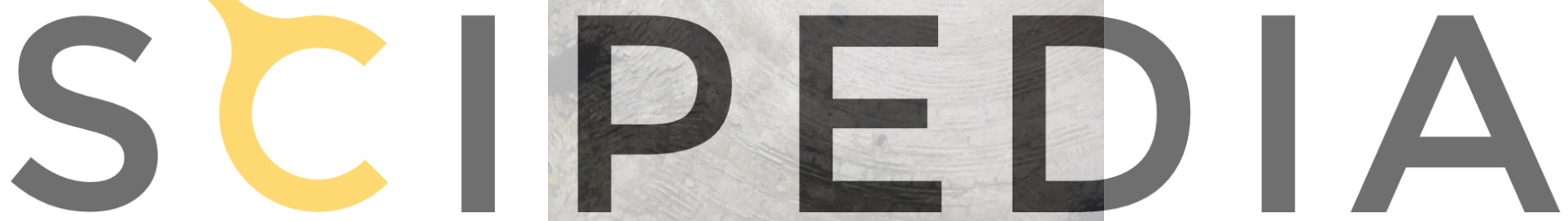

Register for free at https//www.scipedia.com to download the version without the watermark

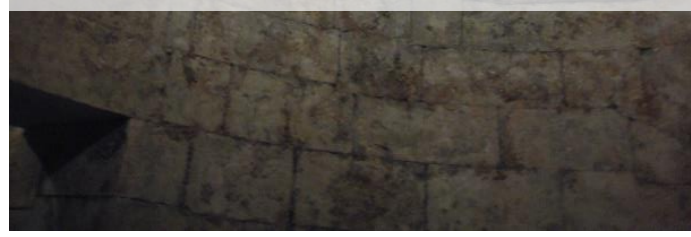

Figure 5: Dome of the circular room (photograph by the author)

\subsection{Dome of the "crypt" of the Mausoleum}

The dome of the so-called crypt, or substructure of the Diocletian's Mausoleum, is interesting for the research of the vaults of the substructures of the imperial apartments, although it is not physically connected to them. The dome, spanning $8.25 \mathrm{~m}$, is constructed of Roman concrete, without any covering layer; in fact, the imprints of formwork are still visible on its intrados. (G. Nikšić, personal communication, July 2015). 

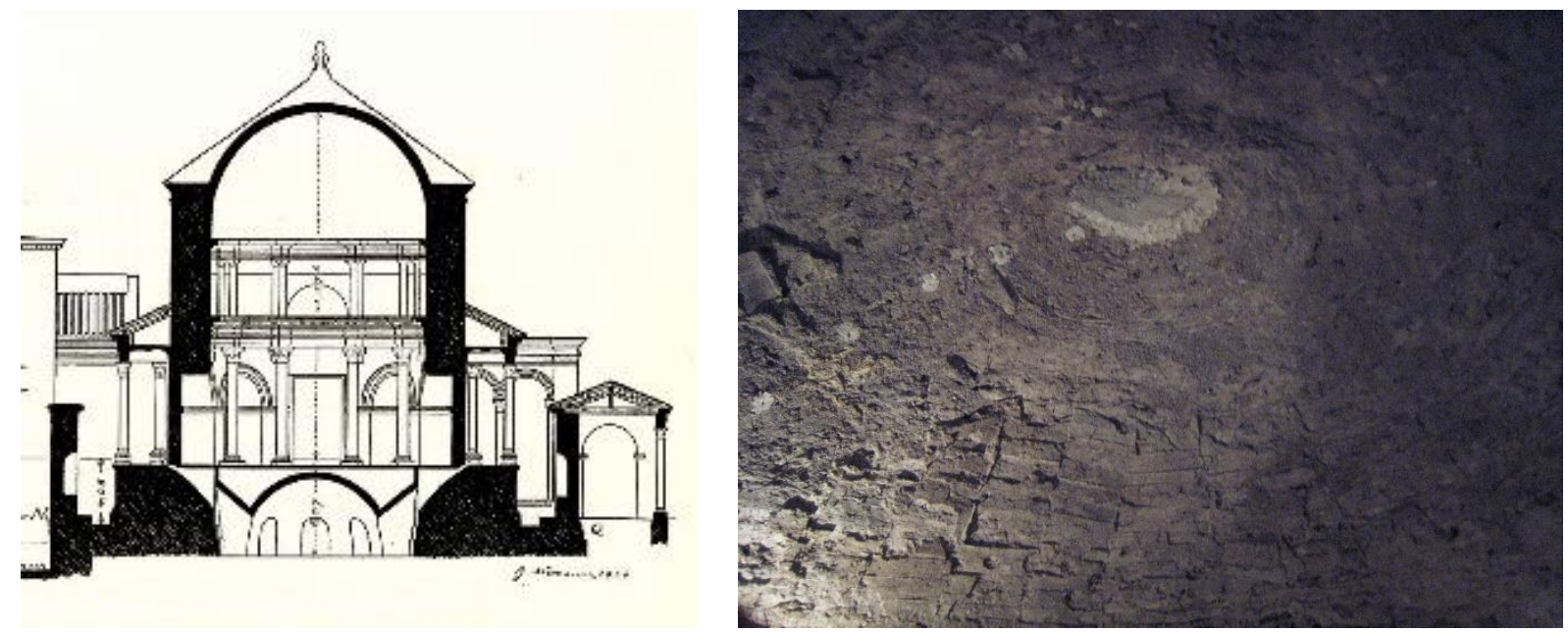

Figure 6: Mausoleum of the emperor Diocletian (by Niemann 1910)

Figure 7: the dome of the crypt of the Mausoleum with the imprints of formwork

\section{CONCLUSIONS}

\subsection{Vaults of the substructures - Types and materials}

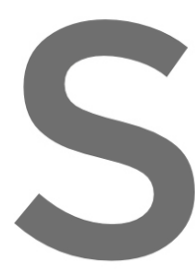

\section{The solution of vaults}

palace is a logical and sim

to the complex disposi

display a great variety i

For spanning rooms of
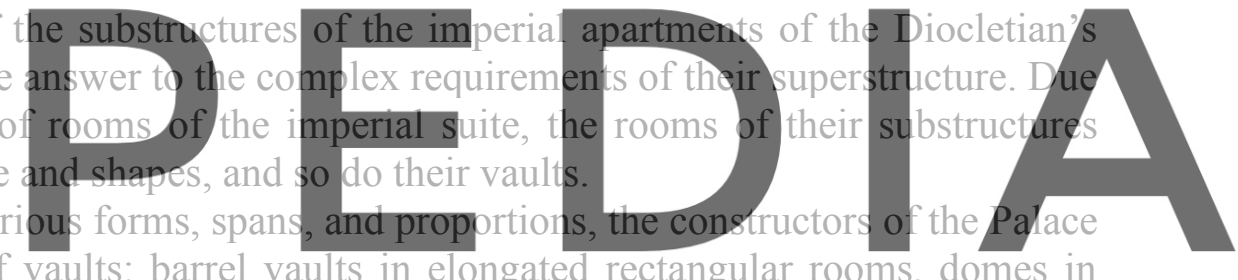

constructed various types of vaults: barrel vaults in elongated rectangular rooms, domes in

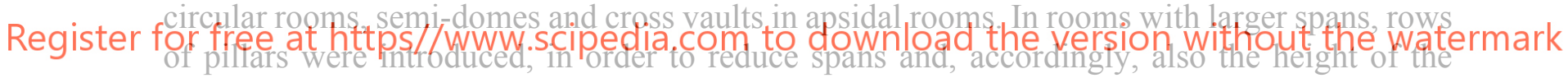

vaults, because the substructures, including their vaults, had to form a horizontal platform for

the imperial apartments. In these rooms cross vaults were constructed, to concentrate loads and forces into the non-continuous bearings of pillars.

The material of the vaults has not been systematically analyzed. Systematic excavation of the substructures of the Diocletian's palace began only in the mid- $20^{\text {th }}$ century. It is easy to recognize the material of the vertical structures - walls and pillars: it is local limestone, in large precisely cut blocks. On the other hand, the material of the vaults is not so easy to recognize.

Because in the mid- $20^{\text {th }}$ century the vaults of the central hall of substructures were considered not to be structurally sound, they were repaired without proper research on the materials and techniques used for their construction, which resulted in inadequate reconstruction of these vaults.

The vaults of the central hall of substructures, reconstructed in a modern material (prestressed concrete) with a stone lining which gives the appearance of a stone vault, could be misleading: it was believed that the vaults of substructures were stone masonry structures (G. Nikšić, personal communication, January 2020). The thesis that the major part of the substructure vaults was made out of stone can be easily refuted by simply observing the intrados 
of the vaults. As they were only a substructure without other function, they have never been plastered, so the texture of the vaults is clearly visible.

The intrados of the vaults is rough, with visible irregular pieces of tufa inserted into thick mortar; some of them are faced with opus mixtum, with rows of brick between stone layers. These vaults are not stone vaults, as interpreted by some scholars; the pieces of tufa are not constructed in a regular masonry bond: in fact, they are caementa of the opus caementicium. The vaults of the substructures are built of Roman concrete, made without harena fossicia: in fact, the complex of vaults of the Diocletian's palace's substructures is an important, precisely dated structure of opus signinum, constructed by skillful builders employed specially for an important imperial building.

The intrados of certain vaults are faced in the opus mixtum technique: the intrados of the upper parts of domes and semi-domes is made of bricks. According to G. Nikšić, brick was one of important materials used for building the Diocletian's palace because of the tight deadline within which all the construction work should have been completed. ${ }^{14}$

Whether the upper parts of domes and semi-domes were constructed of brick in their whole thickness or is the visible surface of intrados just a brick lining of a concrete dome - this cannot be asserted with certainty without further investigation. However, it is more likely that the bricks are only a lining of the intrados of the dome. The fact that the lower part of the dome is constructed of concrete faced by opus mixtum ascertains this claim; the concrete dome of the crypt of the Mausoleum is another argument for this hypothesis.
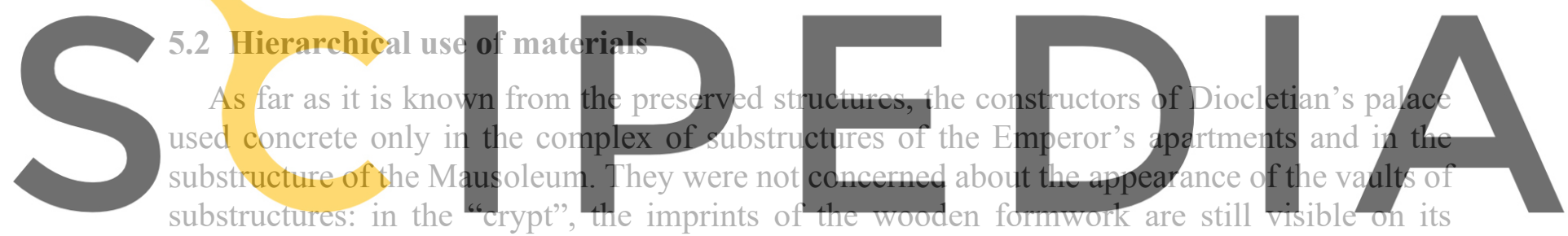

concrete dome. For the representative vaults (the ones of the Mausoleum and of the so-called

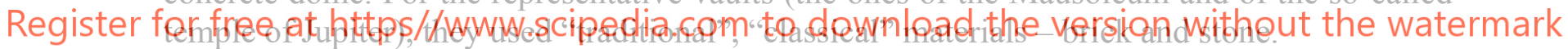

The tradition of building with opus caementicium was at the end of $3^{\text {rd }}$ - beginning of $4^{\text {th }}$

century already well established. In Rome itself the most representative large-span vaults and domes had been erected in opus caementicium. We can hypothesize that, for some reasons, several centuries after the Pantheon had been built, constructors of the Diocletian's palace appreciated the "traditional", "natural" materials higher then concrete.

In a way, the attitude of the architects of the Diocletian's palace toward opus caementicium seems to have returned to the practice of the architects in the initial phase of construction with Roman concrete: the use of Roman concrete in the substructures of Diocletian's palace (and not in the representative parts of structures) has a direct parallel in the structural concept of the sanctuaries of Jupiter Anxur at Terracina, of Fortuna Primigenia at Praeneste (Palestrina), and of that of Hercules Victor at Tibur (Tivoli); in these complexes, built in the first century AD, the substructures were built of opus caementicium, and the temples upon them were constructed of stone. 6,7

The use of concrete spread first to utilitarian buildings like markets, thermae etc. ${ }^{7}$ The first large concrete dome, still preserved, is the dome of the so-called "Temple of Mercury" at Baiae (diameter $21.6 \mathrm{~m}$ ). The domed edifice, built in the late first century BC, was actually part of 
thermae. ${ }^{6}$ Temples, the most traditional building type in Roman architecture, were constructed in the traditional form and materials for several centuries after the early examples of concrete substructures had been built. In 118-128 AD the largest dome made of Roman concrete, the one of the Pantheon in Rome (diameter $43.3 \mathrm{~m}$ ), was built, ${ }^{7}$ testifying that by then opus caementicium was acknowledged as a "noble" material, suitable for the most representative edifices, and irreplaceable for large-span vaulting.

Analyzing the preserved structures of the palace of Diocletian, it could be concluded that the approach and taste of the investor and of his architects changed. The traditionalism in the choice of materials for different parts of the Palace, i.e. for its representative and utilitarian parts, should not be surprising in a complex of buildings constructed as a residence of an emperor.

In ancient Rome (and in other ancient civilisations) the meaning of materials and colours was defined: e.g. porphyry (used for imperial sarcophagi, for the well-known statue of Tetrarchs and for other imperial statues and decorative elements) symbolized imperial power. Maybe similar rules and traditions also determined the use of materials in the Diocletian's palace.

Acknowledgements. I wish to express my most sincere gratitude to Prof. Dr. Goran Nikšić for sharing his great knowledge on the structures of the Palace of Diocletian in Split. I would like to acknowledge and thank Mrs. Branka Brekalo, the director of the Museum of the town of Split and to the staff of the Museum, for enabling me to do research within the substructures of the Diocletian's palace, and to Mrs. Jasna Jerkov, the director of the Department for the Old City Core of Split, for giving me access to the survey plans of the substructures.

\section{REFERENCES}

[1] Adam, R. Ruins of the Palace of the Emperor Diocletian at Spalatro in Dalmatia. (1764).

[2] Fischer von Erlach, J. B. Entwurff einer historischen Architektur. (1725).

[3] Marasović, T. Diocletian's Palace, Sloboda, (1982).

[4] Niemann, G. Der Palast Diokletians in Spalato. Hölder, (1910).

[5] Vitruvius, M. P. De architectura libri decem.

[6] Lancaster, L. C. Concrete Vaulted Construction in Imperial Rome. Cambridge University Press, (2005).

[7] Ward-Perkins, J. B. Architettura Romana. Electa Editrice, (1979).

[8] Lamprecht, H.-O. Opus caementitium - Bautechnik der Römer. Beton-Verlag, (1987).

[9] Historical Complex of Split with the Palace of Diocletian. http://whc.unesco.org/en/list/97 (retrieved January 23, 2020)

[10] Nikšić, G. Dioklecijanova palača - od projekta do izvedbe (Diocletian's Palace - from Design to Construction). In: N. Cambi et al. (Eds): Dioklecijan, tetrarhija i Dioklecijanova palača o 1700. obljetnici postojanja (Diocletian, Tetrarchy and Diocletian's Palace on the 1700th Anniversary of Existence), Književni krug Split (2009), pp. 117-134.

[11] Bužančić, R. Dioklecijanova palača (Diocletian's Palace). In: N. Cambi et al. (Eds): Dioklecijan, tetrarhija i Dioklecijanova palača o 1700. obljetnici postojanja (Diocletian, Tetrarchy and Diocletian's Palace on the 1700th Anniversary of Existence), Književni krug Split (2009), pp. 235-278.

[12] Survey plan of the substructures of Diocletian's Palace, Department for the Old City Core of Split (unpublished) 
[13]Diocletian's Palace and the Historical Nucleus of Split (extension). http://whc.unesco.org/en/tentativelists/2015/ (retrieved January 28, 2020)

[14] Nikšić, G. The use of brick in Diocletian's Palace at Split, Archeologia dell'Architettura (2015) 20: 206-209.

[15] Nikšić, G. Prilog o arhitekturi Dioklecijanovog mauzoleja i rekonstrukciji splitske katedrale u 13. stoljeću. Prilozi povijesti umjetnosti u Dalmaciji (1997) 35: 105-122.

[16] Jackson, T. G. Dalmatia, the Quarnero and Istria, with Cettigne in Montenegro and the Island of Grado. Clarendon Press (1887).

[17] Nikšić, G. The Influence of Building Materials on Architectural Design: Dalmatian Stone at the Cathedrals in Korčula and Šibenik. In: A. Payne (Ed.): Dalmatia and the Mediterranean: Portable Archeology and the Poetics of Influence. Brill (2014) pp. 382401

[18] Lancaster, L. C. Innovative vaulting in the architecture of the Roman Empire. Cambridge University Press (2015). 